\title{
Inhibitory effect of curcumin on testosterone induced benign prostatic hyperplasia rat model
}

\author{
Su Kang Kim ${ }^{1 \dagger}$, Hosik Seok ${ }^{1 \dagger}$, Hae Jeong Park', Hye Sook Jeon', Sang Wook Kang ${ }^{1}$, Byung-Cheol Lee ${ }^{2}$, Jooil Yi ${ }^{2}$, \\ Sang Yeol Song ${ }^{2}$, Sang Hyub Lee ${ }^{3}$, Young Ock Kim ${ }^{4}$ and Joo-Ho Chung ${ }^{1 *}$
}

\begin{abstract}
Background: Benign prostatic hyperplasia $(\mathrm{BPH})$ is one of the common male diseases, which is provoked by dihydrotestosterone (DHT) and androgen signals. Several studies showed that curcumin has various effects of prevention and treatment to diseases. We investigated whether curcumin may repress the development of BPH in male Wistar rats.

Methods: Seven weeks male Wistar rats were and divided into 4 groups (normal group, BPH group, finasteride group, curcumin group; $n=8$ for each group). In order to induce BPH in rats, rats were castrated and testosterone was injected subcutaneously everyday (s.c., $20 \mathrm{mg} / \mathrm{kg}$ ). Rats in the curcumin group were treated $50 \mathrm{mg} / \mathrm{kg}$, administered orally for 4 weeks. After 4 weeks, all rats were sacrificed and their prostate and serum were analyzed.

Results: Compared to the finasteride group as positive group, the curcumin group showed similarly protective effect on BPH in histopathologic morphology, prostate volume. Results of immunohistochemistry and western-blot showed decreased expressions of VEGF, TGF-ß1, and IGF1 were also decreased in the curcumin group.
\end{abstract}

Conclusions: These results suggested that curcumin inhibited the development of BPH and might a useful herbal treatment or functional food for BPH.

Keywords: Curcumin, Benign prostatic hyperplasia, Testosterone, BPH

\section{Background}

Benign prostatic hyperplasia (BPH) is a common male disease causing lower urinary tract distress in aging men [1]. Several studies suggested that BPH is a multifactorial disease [2], however, it has known that hormonal factor contributes to the hyperplastic growth of prostate [1].

Underlying etiology of $\mathrm{BPH}$ has not been completely identified, however, it has been well established that the prostate gland in the aging men is affected by androgens. Many researchers reported steroid 5-alpha reductase, which converts testosterone in serum into dihydrotestosterone (DHT) in target tissue, as most important factor in current BPH treatment [3]. DHT synthesized by steroid 5-alpha reductase increases as aging, hence, prostatic gland of aged man may be affected more by steroid 5-alpha reductase [4]. Conventional steroid 5-alpha

\footnotetext{
* Correspondence: jhchung@khu.ac.kr

${ }^{\dagger}$ Equal contributors

'Kohwang Medical Research Institute, School of Medicine, Kyung Hee University, Seoul 130-701, Republic of Korea

Full list of author information is available at the end of the article
}

reductase inhibitors, such as finasteride and dutasteride, were successful in the treatment of hyperplastic growth of prostate, however, these drugs were responsible for adverse effects, such as gynecomastia, dizziness, upper respiratory infections, headache, and chest pain $[5,6]$. Such effect may limit the use of conventional drugs for $\mathrm{BPH}$, however, might be avoided by commonly used safe agents.

Curcumin is widespread, inexpensive, and highly safe to human [7]. It is polyphenolic natural compound from Curcuma longa [8], with diverse drug activities against aging related events, including dermatologic changes [9], retinal diseases [10], Parkinson's disease (PD) [11], renal antioxidative effect [12], ischemic oxidative damages in diverse organs [13-15], and cancers [16]. Curcumin analogues may facilitate degradation of androgen receptor (AR) in prostate cancer [17], and may induce apoptosis of prostate cancer cell by IkBalpha, c-Jun and androgen receptor [18]. Curcumin shows suppressive effect on HIF1a $[19,20]$, which was suggested as a key molecule 
Table 1 Effects of curcumin on body weight in each group

\begin{tabular}{lllll}
\hline & Normal & BPH & Curcumin & Finasteride \\
\hline Body weight (g) & & & & \\
Initial weight & 250 & 250 & 350 & $368.34 \pm 5.43$ \\
Final weight & $362.23 \pm 5.72$ & $365.50 \pm 6.26$ & $118.34 \pm 5.43$ & $367.50 \pm 6.75$ \\
Total body weight & $112.23 \pm 5.72$ & $115.50 \pm 6.26$ & & $117.50 \pm 6.75$ \\
gains for 30 days & & & & \\
\hline
\end{tabular}

Data are presented as mean \pm S.E. $(n=8)$

Normal, normal group; $\mathrm{BPH}$, testosterone induced BPH group; curcumin, testosterone induced BPH with curcumin (200 mg/ml) group; finasteride, testosterone induced $\mathrm{BPH}$ with finasteride $(1 \mathrm{mg} / \mathrm{ml})$ group

for transition from prostatitis to $\mathrm{BPH}$ [21]. Moreover, it was proven to be a potent TNF blocker [7], and its antioxidant effect may suppress LOX1 [22]. Administration of curcumin was investigated as liposomal-formulated curcumin in Parkinson's disease (PD) [11], and lecithinized curcumin delivery system in BPH [23].

These previous reports indicate that curcumin may have protective role in $\mathrm{BPH}$, however, effect of curcumin on $\mathrm{BPH}$ has not been investigated, which is responsible for the synthesis of DHT, an active metabolite of testosterone. Therefore, we investigated whether the curcumin has protective on testosterone induced $\mathrm{BPH}$ rat model.

\section{Methods}

\section{Preparation of the curcumin}

The chemical structure of curcumin was purchased from SAMCHUN (\#121703 Pyongtack, Korea).

\section{Animals}

The animals used in this study were 7 weeks male Wistar (Central Lab Animal Inc, Korea) with an average body weight of $250 \pm 10 \mathrm{~g}$. The animal room was maintained at $22 \pm 2{ }^{\circ} \mathrm{C}$ and at $40 \sim 70 \%$ relative humidity. Room lighting consisted of $12 \mathrm{~h}$ periods of light and dark. All experiments were carried out according to the protocols approved by the Animal Care Committee of the Animal Center at Kyung Hee University and in accordance with guidelines from the Korean National Health Institute of Health Animal Facility.

\section{Induction of BPH and treatments}

After orchiectomy, the rats were divided into four groups $(n=8)$. BPH was induced by subcutaneous injection of testosterone $(20 \mathrm{mg} / \mathrm{kg})$ for 4 weeks: (A) a normal group; (B) BPH that induced testosterone group, injected subcutaneously; $(C)$ curcumin group that treated $50 \mathrm{mg} / \mathrm{kg}$, administered orally for 4 weeks; (D) finasteride group that treated $1 \mathrm{mg} / \mathrm{kg}$, administered orally, as a positive anti-BPH drug and was purchased from Sigma-Aldrich (St Louis, MO, USA). The dosage of curcumin $(50 \mathrm{mg} / \mathrm{kg}$ ) referred to previous study [7]. All materials were administered to animals once daily for 4 weeks, and body weight was measured weekly. After 4 weeks, all animals were fasted overnight. Blood was collected in EDTA tubes, placed on ice, serum immediately was separated and stored at $-20^{\circ} \mathrm{C}$. After animals were sacrificed, fresh prostate was stored in formaldehyde solution for light microscopic observation. The rest of the prostate were stored at $-70{ }^{\circ} \mathrm{C}$ for the later analysis.

\section{Blood collection and biochemical analysis}

At the end of the experiment, the food was removed and experiments were performed between $9 \mathrm{AM}$ and $12 \mathrm{PM}$. Blood samples were obtained in serum separating tube (SST) from the heart of rat at the end of the experiment. Blood samples were centrifuged at $3000 \times \mathrm{g}$ for $15 \mathrm{~min}$, at $4{ }^{\circ} \mathrm{C}$ and serum was obtained and stored at $-70{ }^{\circ} \mathrm{C}$ before analyzed biochemical test. Glucose, total protein, GOT (glutamic oxaloacetic transaminase), and GPT (glutamic pyruvic transaminase), were analyzed by Greenlab (Seoul, Korea).

\section{Histopathological examination}

Fixed prostate tissue embedded in paraffin wax was cut into $5 \mu \mathrm{m}$ thick sections. Then the tissues were stained

Table 2 The effect of curcumin in each group

\begin{tabular}{|c|c|c|c|c|}
\hline & Normal & $\mathrm{BPH}$ & Curcumin & Finasteride \\
\hline Glucose (mg/dl) & $137.00 \pm 8.09$ & $115.89 \pm 3.48^{\#}$ & $153.60 \pm 3.18^{* *}$ & $128.58 \pm 5.79$ \\
\hline Total protein (g/dl) & $5.72 \pm 0.06$ & $5.92 \pm 0.06$ & $5.65 \pm 0.12$ & $5.85 \pm 0.09$ \\
\hline AST (GOT) (U/L) & $88.86 \pm 6.50$ & $97.67 \pm 9.69$ & $101.20 \pm 6.86$ & $101.43 \pm 4.92$ \\
\hline $\mathrm{ALT}(\mathrm{GPT})(\mathrm{U} / \mathrm{L})$ & $28.43 \pm 1.80$ & $28.12 \pm 1.53$ & $36.00 \pm 2.22^{\#, *}$ & $28.86 \pm 0.80$ \\
\hline
\end{tabular}

Data are presented as mean \pm S.E. $(n=8)$

${ }^{\#} P<0.05$ compared with normal group; ${ }^{*} P<0.05$, ${ }^{* *} P<0.01$, compared with BPH group 
Table 3 Prostate weight, prostate volume, and prostate weight ratio in each group

\begin{tabular}{lllll}
\hline & Normal & BPH & Curcumin & Finasteride \\
\hline Prostate weight $(\mathrm{g})$ & $1.04 \pm 0.04$ & $1.36 \pm 0.03^{\# \# \#}$ & $0.91 \pm 0.05^{* * *}$ & $0.73 \pm 0.03^{* * *}$ \\
Prostate volume $\left(\mathrm{cm}^{3}\right)$ & $1.13 \pm 0.12$ & $1.73 \pm 0.19^{\# \# \#}$ & $0.67 \pm 0.06^{* * *}$ & $0.86 \pm 0.08^{* * *}$ \\
Prostate weight ratio $(\mathrm{mg} / 100 \mathrm{~g}$ of BW) & $0.28 \pm 0.02$ & $0.40 \pm 0.03^{\# \# \#}$ & $0.22 \pm 0.022^{* * *}$ & $0.27 \pm 0.022^{* * *}$ \\
\hline
\end{tabular}

Data are presented as mean \pm S.E. $(n=8)$

$\# \#$ \#\# 0.001 compared with the normal group; ${ }^{* * *} P<0.001$ compared with the BPH group

by Harris' hematoxylin-eosin according to standard procedure. The sections were mounted and cover slipped using mounting solution. Size and thickness of epithelial cell in ventral lobe of prostate tissue was assessed in order to identify effect of curcumin on $\mathrm{BPH}$.

\section{Immunohistochemistry}

Immunostaining was performed on $4 \mu \mathrm{m}$ sections after deparaffinization. Antigen retrieval was performed in citrate buffer $\mathrm{pH} 6.0$ with $95{ }^{\circ} \mathrm{C}$ for 10 min prior to peroxides quenching with $3 \% \mathrm{H}_{2} \mathrm{O}_{2}$ in PBS for 10 min. Then sections were washed with $\mathrm{PBS}$ and preblocked with normal goat or rabbit serum for $10 \mathrm{~min}$. In the step of primary antibody reaction, slides were incubated, respectively, with anti-VEGF (Santa Cruz, CA, USA) in a 1:200 dilution, anti-TGF- $\beta 1$ (Santa Cruz, CA, USA in a 1: 200 dilution, and anti-IGF-1 (Santa Cruz, CA, USA) in a 1: 200 dilution for overnight at $4{ }^{\circ} \mathrm{C}$. Then, the sections were incubated with biotinylated secondary antibodies (1: 1000) for $1 \mathrm{~h}$. Following a washing step with PBS, the streptodavidin-
HRP was applied. Finally, the sections were rinsed in PBS, developed with diaminobenzidine tetrahydrochloride substrate $(\mathrm{DAB})$ in $10 \mathrm{~min}$. At least three random region of each section were examined at $\times 100$ and $\times 400$.

\section{Western-blot}

Prostate tissues were homogenized by a tissue homogenizer in protein lysis buffer. After centrifuge at 12,000 rpm, protein was extracted and protein concentration was determined using Bradford protein assay. Proteins were transferred membranes and membranes were incubated with the antibodies used for western-blot analysis were anti-VEGF (Santa Cruz, CA, USA) in a 1:200 dilution, anti-TGF- $\beta 1$ (Santa Cruz, CA, USA in a $1: 200$ dilution, and anti-IGF-1 (Santa Cruz, CA, USA) for overnight. Then, HRP-conjugated secondary antibody (1:5000, Pierce Chemical) for $1 \mathrm{~h}$ at room temperature (RT) and membrane was developed with ECL western blotting detection reagents (GE Healthcare Biosciences, Pittsburgh, PA, USA).
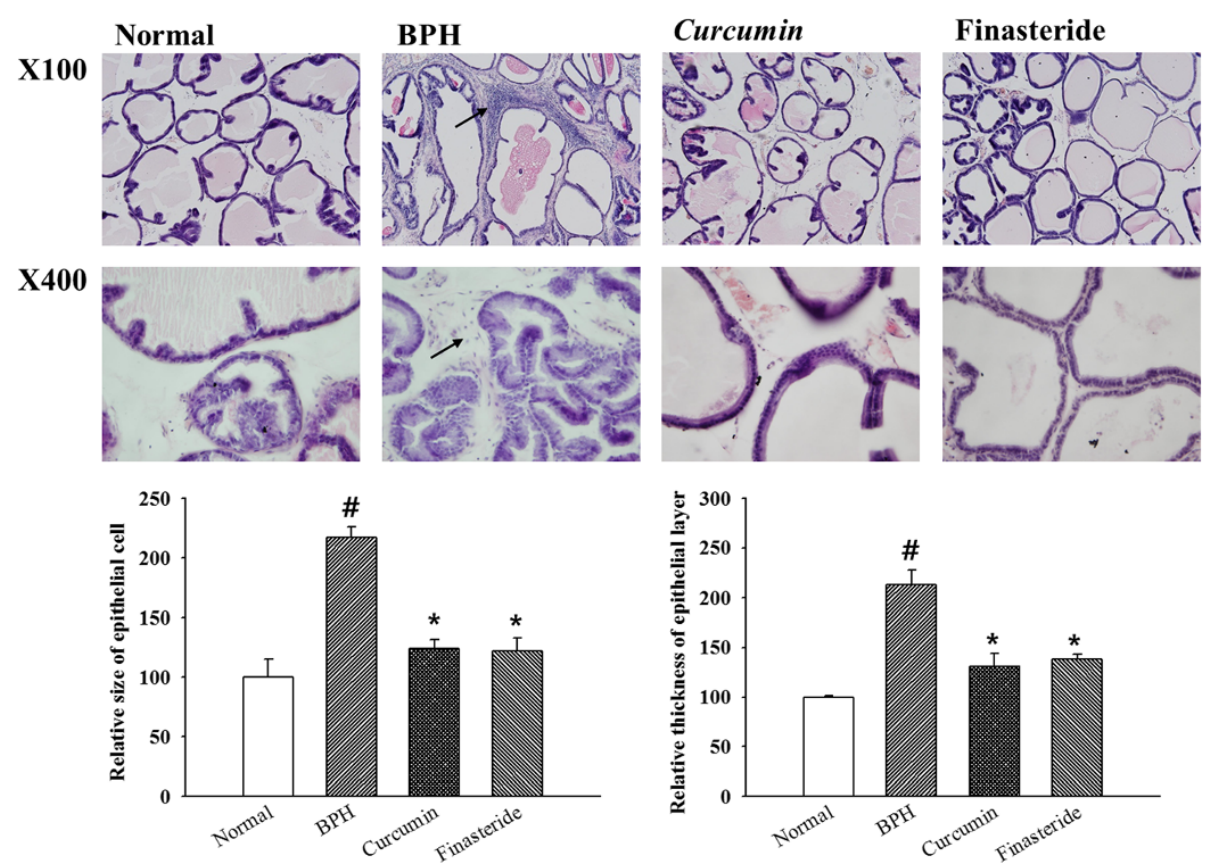

Fig. 1 H\&E stains of prostate tissue in each group $(\times 100$ and $\times 400)$. Arrowheads indicate interacina fibrosis in ventral lobe of prostate tissue. \# $P<0.05$ compared with the normal group; ${ }^{*} P<0.05$ compared with the BPH group 


\section{Statistical analyses}

All of the values showed as the mean \pm S.E. Significant difference among the groups was statistically performed using a one-way analysis of variances (ANOVA), followed by a non-parametric post Tukey test. All $p$ values are twotailed, and significance was set at $p<0.05$. All statistical analysis was performed using the SPSS for windows, version 21.0 (SPSS Inc.).

\section{Results}

\section{Measurement of weight change}

Body weight change shows in Table 1. Final body weight was measured after 4 weeks. The final body weight in normal, BPH, curcumin, and finasteride groups was increased compared with initial body weight (normal group, 69. $06 \%$, BPH group, $68.49 \%$, curcumin group, $67.93 \%$, and finasteride group $68.12 \%$, respectively). The differences among each groups did not show significant difference $(p>0.05)$.

\section{Glucose, total protein, AST, and ALT level in serum level}

The BPH group demonstrated decrease glucose level in serum than the normal group (Table 2). Curcumin treatment group showed effect on plasma glucose. AST level in serum did not significantly different among groups. However, ALT level in curcumin group showed higher than other groups. And, total protein level in serum in the $\mathrm{BPH}$ group was slightly increased, compared with the normal group. However, differences among the groups were not statically significant $(p>0.05)$. The total protein of curcumin group showed decrease compared with that of the normal group.

\section{Prostate ratio according to volume and weight of the prostate}

Prostate weight, volume, and weight ratio show in Table 3. Prostate weight of the BPH group $(1.36 \pm 0.03 \mathrm{~g}$, mean \pm S.E.) was significantly increased compared

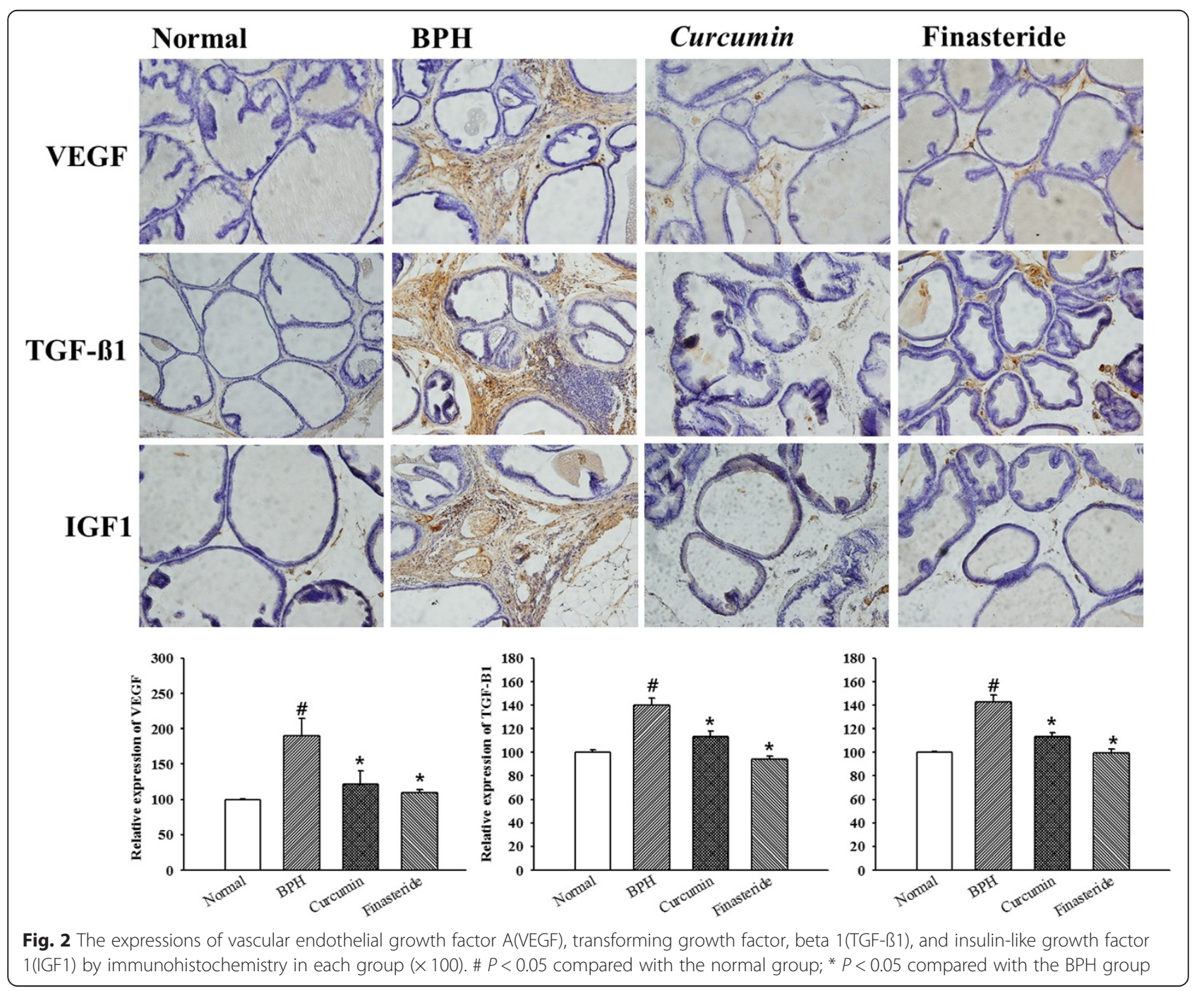


with that of the normal group $(1.04 \pm 0.04 \mathrm{~g})$, and the administration groups of curcumin and finasteride treatment group were significantly decreased than that of the BPH group, $0.91 \pm 0.05 \mathrm{~g}$ and $0.73 \pm 0.03 \mathrm{~g}$, respectively. The prostate volume of $\mathrm{BPH}$ group (1.73 $\left.\pm 0.19 \mathrm{~cm}^{3}\right)$ was significantly higher than that of normal group $\left(1.13 \pm 0.12 \mathrm{~cm}^{3}\right)$, and the administration groups of curcumin and finasteride group were significantly lower than that of BPH group, $0.67 \pm$ $0.06 \mathrm{~cm}^{3}$ and $0.86 \pm 0.08 \mathrm{~cm}^{3}$, respectively. Finally, prostate weight ratio of the $\mathrm{BPH}$ group $(0.40 \pm$ $0.03 \mathrm{mg} / 100 \mathrm{~g}$ of $\mathrm{BW})$ was significantly higher than that of the normal group $0.28 \pm 0.02 \mathrm{mg} / 100 \mathrm{~g}$ of BW), and the administration groups of curcumin group and finasteride group were significantly lower than that of the $\mathrm{BPH}$ group, $0.22 \pm 0.02 \mathrm{mg} / 100 \mathrm{~g}$ of $\mathrm{BW}$ and $0.27 \pm$ $0.02 \mathrm{mg} / 100 \mathrm{~g}$ of BW, respectively.

\section{Histological morphology of the prostate}

In order to examine the effects of the administration of curcumin on histological morphology of prostate tissue, H\&E staining was performed. Prostate of rats generally consists of three distinct including dorsal lobe, lateral lobe, and ventral lobe. We analyzed ventral lobe of prostate tissue. As shown in Fig. 1, the histological morphology of the prostate tissue in the $\mathrm{BPH}$ group was abnormal. The connective tissue in prostate was increased oval shape and size. The epithelial cell layer and lumen space in the BPH group were increased than those of the normal group. And there was interacinar fibrosis in ventral lobe of rats in the $\mathrm{BPH}$ group. The decreases in hyperplasia and the epithelial layer thickness were observed in the curcumin group and the finasteride group as positive group compared with those of the BPH group $(p<0.05)$.

\section{Expression of VEGF, TGF- $B 1$, and IGF1 of prostate tissue}

In order to examine the effects of the administration of curcumin on expression of growth factors in prostate tissue, IHC and western-blot were performed. As shown in Figs 2 and 3, the protein expressions of growth factors (VEGF, TGF- 31 , and IGF1) in the BPH group were increased than those of the normal group $(p<0.05)$. These proteins expressions of VEGF, TGF-ß1, and IGF1 both curcumin group and finasteride group showed decrease compared with those of the BPH group $(p<0.05)$.

\section{Discussion}

In previous researches, blockade of steroid 5-alpha reductase was associated with inhibition of development of BPH [1]. Previous evidences for inhibition effect on $\mathrm{BPH}$ development in rats were found by reduction of

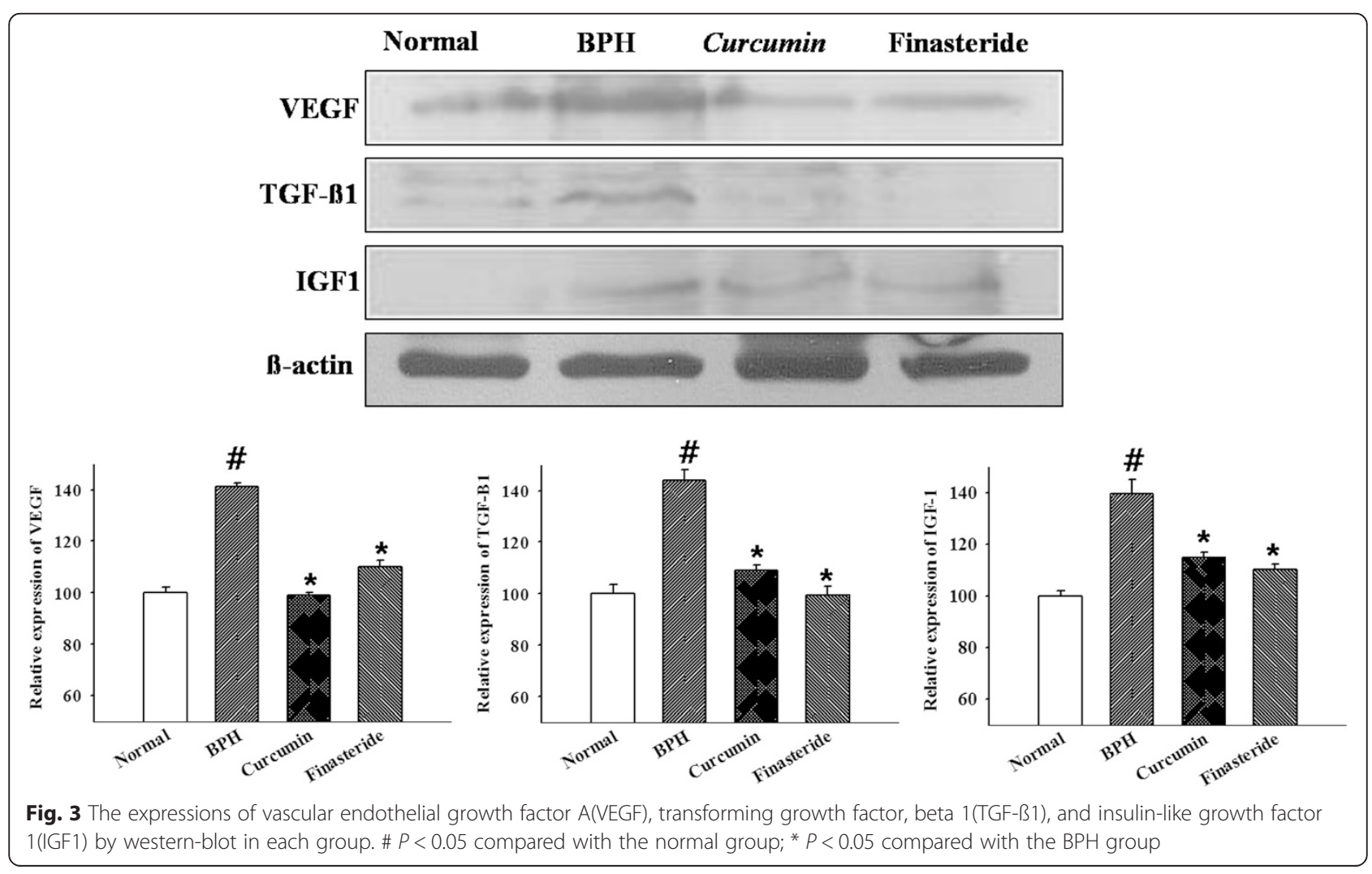


prostate size or decreased histopahthologic morphology of BPH [21, 24].

Prostate require high levels of steroid androgens even for the maintenance of tissue architecture and AR [25]. Testosterone and DHT may influence cell signals by AR, which is nuclear sex steroid hormone receptor, and plays a role in activation of growth factors $[4,26]$. Such role in the prostate has permissive effect in transformation from normal prostate to $\mathrm{BPH}$ or prostatic cancer [27-29]. Whether which of AR-activated growth factors may affect BPH development may be ambiguous, however, there were some previous evidences that decreased expressions of VEGF, TGF- $\beta 1$ [30, 31], and IGF1 [32, 33] were associated with inhibition of hyperplastic growth of prostate [29]. VEGF may be associated with angiogenic growth in hyperplasia [34]. Stromal extracellular matrix (ECM) accumulation is implicated in hyperplastic growth of BPH $[26,35,36]$, and TGF- $ß 1$ may affect the process of ECM deposition and inflammatory signals [37]. And last, IGF signaling was indicated to be responsible for the prostatic enlargement [38] and LUTS with obesity and diabetes [33].

It has been also known that such factors may be inhibited by curcumin. Curcumin may inhibit mitogenic effect of IGF1 and IGF1R signals in hypertrophic cells [39, 40]. Moreover, it may regulate various molecular targets including EGF, PDGF, VEGF, NF-kB, and STAT3 in cancers [41]. Regulation of VEGF by curcumin is seen in agerelated macular degeneration model of mouse [42]. TGFbeta responses induced by cellular damages [43] and $\mathrm{T}$ cell-dependent inflammatory stress [44] may be reduced by curcumin. And chronic immune-mediated stress may be ameliorated by curcumin $[45,46]$. These previous reports suggest that curcumin may have some beneficial effects on aging-related changes of various body organs, including prostate [18].

In the present study, curcumin showed positive effect of morphology in prostate ratio and histopathology in BPH rat model. Moreover, curcumin showed decreased expression of VEGF, TGF- 31 , and IGF1 when compared to testosterone induced $\mathrm{BPH}$ group. Our result is in concordance with previous reports that curcumin inhibited the expression of the growth factors, and that curcumin may inhibit androgen effect on prostate.

\section{Conclusion}

In summary, curcumin significantly lower prostate weight and prostate volume. And curcumin treatment decreased expressions VEGF, TGF- $\$ 1$, and IGF1 among growth factors in prostate tissue.

These findings suggested that curcumin inhibited the development of $\mathrm{BPH}$ and might by a useful herbal treatment.

\section{Abbreviations}

BPH: Benign prostatic hyperplasia; DHT: Dihydrotestosterone; AR: Androgen receptor; PD: Parkinson's disease; GOT: Glutamic oxaloacetic transaminase; GPT: Glutamic pyruvic transaminase; ANOVA: One-way analysis of variances; $\mathrm{HC}$ : Immunohistochemistry.

\section{Competing interests}

The authors declare that they have no competing interests.

\section{Authors' contributions}

SKK and HS carried out the animal experiment, drafted the manuscript. HJP and HSJ carried out the IHC. SWK, JY, SYS, and SHL participated in analysis morphology of prostate and statistical analysis. BCL, YOK, and $\mathrm{HCC}$ conceived of the study, and participated in its design and coordination and helped to draft the manuscript. All authors read and approved the final manuscript.

\section{Acknowledgments}

This work was carried out with the support of "Cooperative Research Program for Agriculture Science \& Technology Development (Project No. PJ009558)" Rural Development Administration, Republic of Korea.

\section{Author details}

${ }^{1}$ Kohwang Medical Research Institute, School of Medicine, Kyung Hee University, Seoul 130-701, Republic of Korea. ${ }^{2}$ Department of Internal Medicine, College of Oriental Medicine, Kyung Hee University, Seoul 130-702, Republic of Korea. ${ }^{3}$ Department of Urology, College of Medicine, Kyung Hee University, Seoul 130-702, Republic of Korea. ${ }^{4}$ Development of Ginseng and Medical Plants Research Institute, Rural Administration, Eumseong 369-873, Republic of Korea.

Received: 15 November 2013 Accepted: 25 August 2015

Published online: 22 October 2015

\section{References}

1. Lee YJ, Jeong SJ, Byun SS, Lee JJ, Han JW, Kim KW. Prevalence and correlates of nocturia in community-dwelling older men: results from the korean longitudinal study on health and aging. Korean J Urol. 2012;53(4):263-7.

2. Nandeesha H. Benign prostatic hyperplasia: dietary and metabolic risk factors. Int Urol Nephrol. 2008;40(3):649-56.

3. Zhu YS, Imperato-McGinley JL. 5alpha-reductase isozymes and androgen actions in the prostate. Ann N Y Acad Sci. 2009;1155:43-56.

4. Carson 3rd C, Rittmaster R. The role of dihydrotestosterone in benign prostatic hyperplasia. Urology. 2003;61(4 Suppl 1):2-7.

5. Uygur MC, Gur E, Arik Al, Altug U, Erol D. Erectile dysfunction following treatments of benign prostatic hyperplasia: a prospective study. Andrologia. 1998;30(1):5-10

6. Patel AK, Chapple CR. Medical management of lower urinary tract symptoms in men: current treatment and future approaches. Nat Clin Pract Urol. 2008;5(4):211-9.

7. Aggarwal BB, Gupta SC, Sung B. Curcumin: an orally bioavailable blocker of TNF and other pro-inflammatory biomarkers. Br J Pharmacol. 2013;169(8):1672-92.

8. Sahebkar A. A systematic review and meta-analysis of randomized controlled trials investigating the effects of curcumin on blood lipid levels. Clin Nutr. 2013;33(3):406-14.

9. Nguyen TA, Friedman AJ. Curcumin: a novel treatment for skin-related disorders. J Drugs Dermatol. 2013:12(10):1131-7.

10. Wang LL, Sun Y, Huang K, Zheng L. Curcumin, a potential therapeutic candidate for retinal diseases. Mol Nutr Food Res. 2013;57(9):1557-68.

11. Chiu S, Terpstra KJ, Bureau Y, Hou J, Raheb H, Cernvosky Z, et al. Liposomalformulated curcumin [Lipocurc] targeting HDAC (Histone Deacetylase) prevents apoptosis and improves motor deficits in Park 7 (DJ-1)-knockout rat model of Parkinson's disease: implications for epigenetics-based nanotechnologydriven drug platform. J Complement Integr Med. 2013;10(1):75-88.

12. Trujillo J, Chirino YI, Molina-Jijon E, Anderica-Romero AC, Tapia E, Pedraza-Chaverr J. Renoprotective effect of the antioxidant curcumin: Recent findings. Redox Biol. 2013;1(1):448-56.

13. Yang Y, Duan W, Lin Y, Yi W, Liang Z, Yan J, et al. SIRT1 activation by curcumin pretreatment attenuates mitochondrial oxidative damage induced by myocardial ischemia reperfusion injury. Free Radic Biol Med. 2013;65C:667-79. 
14. Okudan N, Belviranli M, Gokbel H, Oz M, Kumak A. Protective effects of curcumin supplementation on intestinal ischemia reperfusion injury. Phytomedicine. 2013;20(10):844-8

15. Zhou JH, Hao ML, Zhao S, Chen HE, Chen D, Ying L, et al. [Effects of curcumin on pneumocyte apoptosis and CHOP in pulmonary ischemia/reperfusion injury of mice]. Zhongguo Ying Yong Sheng Li Xue Za Zhi. 2013;29(4):318-23.

16. Zhou G-Z, Sun G-C, Zhang S-N. Curcumin derivative HBC induces autophagy through activating AMPK signal in A549 cancer cells. Molecular Cellular Toxicol. 2015;11(1):29-34

17. Shi $\mathrm{Q}$, Shih CC, Lee KH. Novel anti-prostate cancer curcumin analogues that enhance androgen receptor degradation activity. Anticancer Agents Med Chem. 2009;9(8):904-12.

18. Guo H, Xu YM, Ye ZQ, Yu JH, Hu XY. Curcumin induces cell cycle arrest and apoptosis of prostate cancer cells by regulating the expression of IkappaBalpha, c-Jun and androgen receptor. Pharmazie. 2013;68(6):431-4.

19. Shan B, Schaaf C, Schmidt A, Lucia K, Buchfelder M, Losa M, et al. Curcumin suppresses HIF1A synthesis and VEGFA release in pituitary adenomas. J Endocrinol. 2012;214(3):389-98.

20. Bae MK, Kim SH, Jeong JW, Lee YM, Kim HS, Kim SR, et al. Curcumin inhibits hypoxia-induced angiogenesis via down-regulation of HIF-1. Oncol Rep. 2006;15(6):1557-62.

21. Kim HJ, Park JW, Cho YS, Cho CH, Kim JS, Shin HW, et al. Pathogenic role of HIF-1alpha in prostate hyperplasia in the presence of chronic inflammation. Biochim Biophys Acta. 2013;1832(1):183-94.

22. Lee HS, Lee MJ, Kim H, Choi SK, Kim JE, Moon HI, et al. Curcumin inhibits TNFalpha-induced lectin-like oxidised LDL receptor-1 (LOX-1) expression and suppresses the inflammatory response in human umbilical vein endothelial cells (HUVECs) by an antioxidant mechanism. J Enzyme Inhib Med Chem. 2010;25(5):720-9.

23. Ledda A, Belcaro G, Dugall M, Luzzi R, Scoccianti M, Togni S, et al. Meriva(R), a lecithinized curcumin delivery system, in the control of benign prostatic hyperplasia: a pilot, product evaluation registry study. Panminerva Med. 2012;54(1 Suppl 4):17-22.

24. Rick FG, Abi-Chaker A, Szalontay L, Perez R, Jaszberenyi $M$, Jayakumar AR, et al. Shrinkage of experimental benign prostatic hyperplasia and reduction of prostatic cell volume by a gastrin-releasing peptide antagonist. Proc Nat Acad Sci U S A. 2013;110(7):2617-22.

25. Corradi LS, Goes RM, Vilamaior PS, Taboga SR. Increased androgen receptor and remodeling in the prostatic stroma after the inhibition of 5-alpha reductase and aromatase in gerbil ventral prostate. Microsc Res Tech. 2009;72(12):939-50.

26. Lai KP, Huang CK, Fang LY, Izumi K, Lo CW, Wood R, et al. Targeting stromal androgen receptor suppresses prolactin-driven benign prostatic hyperplasia (BPH). Mol Endocrinol. 2013;27(10):1617-31.

27. Bartsch G, Rittmaster RS, Klocker H. Dihydrotestosterone and the concept of 5alpha-reductase inhibition in human benign prostatic hyperplasia. Eur Urol. 2000;37(4):367-80

28. Chen Y, Li T, Yu X, Li J, Luo D, Mo Z, et al. The RTKJERK pathway is associated with prostate cancer risk on the SNP level: A pooled analysis of 41 sets of data from case-control studies. Gene. 2013;534(2):286-97.

29. Soulitzis N, Karyotis I, Delakas D, Spandidos DA. Expression analysis of peptide growth factors VEGF, FGF2, TGFB1, EGF and IGF1 in prostate cancer and benign prostatic hyperplasia. Int J Oncol. 2006;29(2):305-14

30. Fuzio P, Ditonno P, Rutigliano M, Battaglia M, Bettocchi C, Loverre A, et al. Regulation of TGF-beta1 expression by androgen deprivation therapy of prostate cancer. Cancer Lett. 2012;318(2):135-44.

31. Rick FG, Schally AV, Block NL, Halmos G, Perez R, Fernandez JB, et al. LHRH antagonist Cetrorelix reduces prostate size and gene expression of proinflammatory cytokines and growth factors in a rat model of benign prostatic hyperplasia. Prostate. 2011;71(7):736-47

32. Yu S, Xia S, Yang D, Wang K, Yeh S, Gao Z, et al. Androgen receptor in human prostate cancer-associated fibroblasts promotes prostate cancer epithelial cell growth and invasion. Med Oncol. 2013;30(3):674.

33. McLaren ID, Jerde TJ, Bushman W. Role of interleukins, IGF and stem cells in BPH. Differentiation. 2011;82(4-5):237-43.

34. Shao JC, Wang Y, Zhang SW, Luo DK, Chang DG, Wu XQ, et al. [Angiogenesis and regulatory factors in rats with $\mathrm{BPH}$ induced by testosterone]. Zhonghua Nan Ke Xue. 2005:11(6):413-8.

35. Niwa S, Ohya S, Kojima Y, Sasaki S, Yamamura H, Sakuragi M, et al. Down-regulation of the large-conductance $\mathrm{Ca}(2+)$-activated $\mathrm{K}+$ channel,
K(Ca)1.1 in the prostatic stromal cells of benign prostate hyperplasia Biol Pharm Bull. 2012;35(5):737-44

36. Cross NA, Reid SV, Harvey AJ, Jokonya N, Eaton CL. Opposing actions of TGFbeta1 and FGF2 on growth, differentiation and extracellular matrix accumulation in prostatic stromal cells. Growth Factors. 2006;24(4):233-41.

37. Descazeaud A, Weinbreck N, Robert G, Vacherot F, Abbou CC, Labrousse F, et al. Transforming growth factor beta-receptor II protein expression in benign prostatic hyperplasia is associated with prostate volume and inflammation. BJU Int. 2011;108(2 Pt 2):E23-8.

38. Kleinberg DL, Ruan W, Yee D, Kovacs KT, Vidal S. Insulin-like growth factor (IGF)-I controls prostate fibromuscular development: IGF-I inhibition prevents both fibromuscular and glandular development in eugonadal mice. Endocrinology. 2007;148(3):1080-8.

39. Youreva V, Kapakos G, Srivastava AK. Insulin-like growth-factor-1-induced PKB signaling and Egr-1 expression is inhibited by curcumin in A-10 vascular smooth muscle cells. Can J Physiol Pharmacol. 2013;91(3):241-7.

40. Kapakos G, Youreva V Srivastava AK. Attenuation of endothelin-1-induced PKB and ERK1/2 signaling, as well as Egr-1 expression, by curcumin in A-10 vascular smooth muscle cells. Can J Physiol Pharmacol. 2012;90(9):1277-85.

41. Shehzad A, Lee J, Lee YS. Curcumin in various cancers. Biofactors. 2013;39(1):56-68.

42. Xie P, Zhang W, Yuan S, Chen Z, Yang Q, Yuan D, et al. Suppression of experimental choroidal neovascularization by curcumin in mice. PLoS One. 2012;7(12):e53329.

43. Cho YJ, Yi CO, Jeon BT, Jeong YY, Kang GM, Lee JE, et al. Curcumin attenuates radiation-induced inflammation and fibrosis in rat lungs. Korean J Physiol Pharmacol. 2013;17(4):267-74.

44. Kim G, Jang MS, Son YM, Seo MJ, Ji SY, Han SH, et al. Curcumin inhibits CD4(+) T cell activation, but augments CD69 expression and TGF-beta1-mediated generation of regulatory T cells at late phase. PLoS One. 2013;8(4):e62300.

45. Jacob A, Chaves L, Eadon MT, Chang A, Quigg RJ, Alexander JJ. Curcumin alleviates immune-complex-mediated glomerulonephritis in factor-H-deficient mice. Immunology. 2013;139(3):328-37.

46. Shehzad A, Rehman G, Lee YS. Curcumin in inflammatory diseases. Biofactors. 2013:39(1):69-77.

\section{Submit your next manuscript to BioMed Central and take full advantage of:}

- Convenient online submission

- Thorough peer review

- No space constraints or color figure charges

- Immediate publication on acceptance

- Inclusion in PubMed, CAS, Scopus and Google Scholar

- Research which is freely available for redistribution

Submit your manuscript at www.biomedcentral.com/submit 